\title{
mSLINTAS
}

33.2.2017 [157-184]

\section{KAPAN ALLAH MEMBUAT SEGALANYA INDAH: MISTERI WAKTU DALAM KITAB PENGKHOTBAH 3:11}

\author{
Andre Putranto Nursantosa ${ }^{1}$ | Graduate Student, Faculty of Philosophy \\ Parahyangan Catholic University \\ Bandung, Indonesia
}

\begin{abstract}
:
"God makes each thing beautiful in its time." This quote has somewhat found its common usage in social media. People have some habit of quoting this expression whenever they encounter difficulties so as to comfort themselves. Through these words, a person might hope earnestly that "God will help me or provide me with the 'beautiful' time someday." But the question that immediately follows is "When?" What if the burden stays and life remains unchanged? Not many of the fans of these wise words know that the saying originates from the Book of Ecclesiastes (3:11), which in itself is a form of ancient Hebrew literature. In the complete verse of the Book, the clause "He hath made every thing beautiful in his time is followed by another clause, "also he hath set the world in their heart, so that no man can find out the work that God maketh from the beginning to the end." The later part of the verse (3:11b) is often ignored. However, by accepting the words that "God hath set the world in their heart", one realises that he or she cannot fathom God's mind, but might make peace and accept that divine question. Hence, one might realise that both good times and the not-so-good times could be but "beautiful times" for oneself.
\end{abstract}

Keywords:

scriptural time - Ecclesiastes $\bullet$ wisdom $\bullet$ vanity $\bullet$ acceptance $\bullet$ mistery $\bullet$ suffering • steadfastness 


\section{Pengantar}

"Segala sesuatu indah pada waktunya". Kata-kata ini sering dikutip lewat mulut banyak orang, melalui media sosial atau ujaran langsung. Katakata ini pun biasa dicantumkan pada kartu undangan perkawinan. Mungkin kutipan ini populer karena mampu menghibur seseorang yang sedang mengalami kemalangan atau situasi sulit dalam hidupnya. Orang sudah berusaha mengatasi kesulitan, tapi situasi yang tidak diharapkan tetap terjadi juga. Kemudian orang berharap Tuhan akan membebaskannya dari masalahnya, memberi yang diharapkannya, yang dalam kutipan tersebut disebut saat yang indah. Akan tetapi, persoalan muncul bersama pertanyaan "Kapankah 'saat indah' itu datang?" "Bagaimana jika 'saat indah' yang diharapkan tidak kunjung datang?” Adakah yang salah dengan ungkapan tersebut? Tidak banyak yang mengetahui bahwa penggalan kalimat "segala sesuatu indah pada waktunya" berasal dari Kitab Pengkhotbah 3:11. "Ia (Allah) membuat segala sesuatu indah pada waktunya, bahkan Ia memberikan kekekalan dalam hati mereka. Tetapi manusia tidak dapat menyelami pekerjaan yang dilakukan Allah dari awal sampai akhir." Melalui artikel ini, saya hendak menelusuri pemaknaan kutipan "segala sesuatu indah pada waktunya" dalam konteks biblisnya, yakni dalam Kitab Pengkhotbah, dan mengeksplorasi maknanya lebih lanjut dalam konteks kini.

\section{Kepengarangan Kitab Pengkhotbah}

\section{Sastra Hikmat}

Pengkhotbah adalah salah satu kitab dalam Perjanjian Lama. Kanon Katolik menggolongkan Pengkhotbah dalam jenis kitab-kitab kebijaksanaan (sastra hikmat), bersama dengan Ayub, Mazmur, Amsal, Kidung Agung, Kebijaksanaan Salomo, dan Putra Sirakh. ${ }^{2}$ Kitab Suci Agama Yahudi (Tanak) menamai kitab ini dengan nama Qobeleth dan tergolong dalam Ketu'bim (tulisan-tulisan). ${ }^{3}$ Ada tiga hal yang perlu disepakati ketika membahas kitab-kitab dalam Sastra Hikmat Perjanjian Lama. Pertama, dengan mengklasifikasikan tujuh kitab di atas sebagai sastra hikmat, tidak berarti menjadikan kitab-kitab lain dalam Perjanjian Lama tidak mengandung hikmat atau 'kebijaksanaan'. Pembagian tujuh kitab di atas 
sebagai sastra hikmat lebih didasarkan pada tradisi, bahwa sejak abad ke13 Gereja Katolik membagi Kitab Suci Perjanjian Lama menjadi tiga golongan: (1) Kitab-Kitab Sejarah, (2) Tulisan-Tulisan Didaktis, dan (3) KitabKitab Nabi, dan yang tergolong tulisan-tulisan didaktis atau Sastra Hikmat adalah kitab Ayub, Mazmur, Amsal, Pengkhotbah, Kidung Agung, Kebijaksanaan Salomo, dan Putra Sirakh ${ }^{4}$.

Kedua, kepengarangan sastra hikmat dalam Perjanjian Lama adalah sesuatu yang kompleks. Yang menyebabkan 'kerumitan' itu adalah yang menghasilkan sastra hikmat dalam dunia Timur Tengah Kuno tidak hanya bangsa Israel, tetapi juga bangsa-bangsa lain, negara-negara tetangga Israel (Mesopotamia dan Mesir). Penulis-penulis kitab-kitab hikmat bangsa Israel adalah para penulis yang muncul kemudian, setelah beredarnya karya-karya sastra hikmat dari negara-negara tetangga yang lain. Dengan demikian kepengarangan sastra hikmat dalam dunia Timur Tengah kuno adalah suatu "gerakan internasional." ${ }^{5}$ Dalam hal ini, pengarang satu negara dalam menulis karya sastranya dapat dipengaruhi tulisan pengarang negara lain. Oleh karena itu, tidak mengherankan jika beberapa tema dalam kitabkitab kebijasanaan Israel memiliki kemiripan dengan tema yang diangkat dalam karya-karya sastra lain negara Timur Tengah. Dalam konteks Pengkhotbah, misalnya, tema bagaimana manusia seharusnya "menikmati hidup" dengan makan, minum dan bersenang-senang dalam kesempatan yang terbatas (Pkh. 2:24-25; 3:12-13; 9:7-10) mirip dengan karya epik terkenal tentang nasihat-nasihat kepada Gilgamesh dalam Kesusastraan Mesopotamia (ANET 90a). ${ }^{6}$

Akhirnya, yang membedakan kepengarangan sastra hikmat Israel dengan sastra hikmat negara-negara tetangga Timur Tengah lain adalah sifat 'Yahwisme'-nya. Dalam hal ini pengarang sastra hikmat Israel senantiasa 'melibatkan' Allah dalam tulisannya, sehingga penyelesaian persoalan kisah dalam karya sastranya tidak sekadar solusi manusiawi, tetapi merupakan pencarian akan kehendak Allah (Yahwe). Di sisi lain karya-karya hikmat non-Israel, lebih bersifat sekular atau andaikata menghadirkan "tuhan", "tuhan" yang dimaksud tidak menunjuk pada Tuhan Allah Israel, sebagaimana diimani bangsa Israel. Hal inilah yang membuat karya-karya hikmat non-Israel hanya menjadi karya sastra biasa. Sebaliknya, karya-karya hikmat Israel (Ayub, Amsal, Pengkhotbah) karena 
sifat Yahwisme-nya diterima (dimasukkan) dalam kanon kitab-kitab, dalam Kitab Suci Yahudi ${ }^{7}$, dan Kitab Suci Kristiani pada akhirnya.

Ketiga, persoalan dalam Sastra Hikmat adalah makna 'hikmat' atau 'kebijaksanaan' itu sendiri. Secara umum 'kebijaksanaan' atau 'hikmat' pada dasarnya adalah "kecakapan untuk mencapai hidup yang sukses atau berhasil ${ }^{8 "}$. Tradisi hikmat (dalam pengertian ini) dimiliki oleh semua bangsa. Hikmat semacam ini adalah "kebenaran umum" (general law) yang diterima masyarakat suatu bangsa karena dalam praktiknya teruji membantu seseorang untuk berhasil dalam hidupnya, jika ditaati atau ditepati.' Dalam tradisi bangsa Israel hikmat semacam ini, mendapatkan kekhasannya karena dikaitkan dengan pengalaman akan Allah. Dengan demikian makna hidup yang 'sukses' juga tidak sekadar hidup berhasil menurut ukuran personal (kesuksesan pribadi), tetapi menjadi hidup yang berkenan dengan kehendak Allah ${ }^{10}$. Dari sinilah Pengajaran hikmat ilahi tumbuh subur baik secara lisan (informal) dan tulisan (formal). Hikmat informal ditanamkan melalui pendidikan dalam keluarga. Hikmat formal tumbuh dan berkembang sejak hadirnya sistem sekolah formal di Israel. Mengapa sekolah formal? Karena dalam sekolah formal dikenallah budaya tulisan yang diajarkan guru kepada murid-muridnya. Dalam sejarah Israel keberadaan sekolah formal terdeteksi sejak sejak zaman raja-raja; raja Salomo dan para penggantinya baik raja di Kerajaan Israel atau raja di Kerajaan Yehuda raja-raja (abad ke-10 SM dan seterusnya). Dari sekolah formal inilah tampil guru-guru kebijaksanaan yang mengajarkan dan 'mewariskan' hikmat tertulis (sastra hikmat) kepada para muridnya atau umat. Demikianlah hikmat informal dan hikmat formal menjadi kekayaan tradisi hikmat bangsa Israel. ${ }^{11}$ Kitab Pengkhotbah adalah salah satu hasil sastra hikmat ini.

\section{Penamaan Kitab}

Dalam Kitab Suci agama Yahudi, kitab Pengkhotbah dinamakan Qobeleth. Dilihat dari asal-usul katanya dalam bahasa Ibrani, istilah Qōhéleth berasal dari akar kata $q$ - $b-l$ yang jika dibentuk menjadi kata benda (= qāhal), berarti "kumpulan banyak orang atau jemaat". Dengan demikian istilah Qobeleth dapat diartikan "seseorang yang mengumpulkan banyak orang atau jemaat". ${ }^{12}$ Kitab Suci berbahasa Yunani (Septuaginta, LXX) menerjemahkan Qoheleth menjadi ekelèsiastes. Terjemahan ini merupakan 
usaha untuk mencari padanan kata qähal, yang dalam bahasa Yunani ditemukanlah kata ekklesia yang bermakna "kumpulan orang". Dari kata ekeklesia diturunkanlah kata ekkelèsiastes yang dipahami sebagai "pemimpin atau pembicara jemaat". Penamaan kitab versi Septuaginta (LXX) ini diturunkan ke dalam versi Kitab Suci berbahasa Latin (Vulgata) dan dalam bahasa Inggris, sehingga dirumuskanlah judul kitab ini: Ecclesiastes. ${ }^{13}$

Martin Luther menerjemahkan Ecclesiastes dalam edisi bahasa Jerman dan menamai kitab ini Der Prediger, yang dalam bahasa Inggris, sepadan dengan istilah The Preacher. LAI (Lembaga Alkitab Indonesia) mengadopsi terjemahan Martin Luther sehingga terumuskanlah nama Pengkhotbah sebagai judul kitab. Dalam tradisi kebijaksanaan formal bangsa Yahudi saat itu, 'Qoheleth' adalah nama julukan (nama sematan) pada guru kebijaksanaan atau cendekiawan Israel yang mengumpulkan dan mengajar para muridnya atau umat di sekolah kebijaksanaan miliknya, ${ }^{14}$ sebagaimana tersurat dalam Pkh. 12:9, "Selain Pengkhotbah berhikmat, ia mengajarkan juga kepada umat itu pengetahuan. Ia menimbang, menguji dan menyusun banyak amsal." 15

\section{Waktu, Bahasa, dan Situasi Sosio-Kultural Seputar Penulisan Kitab Pengkhotbah}

Para ahli memperkirakan bahwa Kitab Pengkhotbah ditulis sekitar akhir abad ke-4 SM atau awal abad ke-3 SM. Kesepakatan para ahli terkait waktu penulisan kitab ini didasarkan oleh bukti-bukti linguistik dikaitkan dengan fenomena sejarah, sebagai berikut.

Pertama, kitab Pengkhotbah ditulis dengan menggunakan bahasa Ibrani, tetapi bahasa Ibrani yang digunakan dalam kitab Pengkhotbah berbeda dengan bahasa-bahasa Ibrani yang digunakan kitab-kitab lain di Perjanjian Lama. Bahasa Ibrani yang digunakan dalam Kitab Pengkhotbah mirip dengan bahasa Ibrani yang digunakan di Mishnah (Mishnaic Hebrew). Mishna (mišnâ) secara harafiah berarti 'pengulangan' ('repetition') menunjuk pada instruksi-instruksi Hukum Taurat-Lisan. Mishnah adalah inti dan bagian tertua dari Talmud. Talmud (talmûd) menunjuk pada otoritas hukum dan tradisi Yahudi pasca terbentuknya kanon Kitab Suci Agama Yahudi. Talmud adalah 'rekaman' (recording) dalam bentuk tulisan dari Hukum Lisan Tradisional (Taurat), yang terdiri atas dua bagian: (1) Mishna yang adalah bagian inti yang lebih tua dan (2) Gemara yang adalah komentar-komentar atas Mishnah. ${ }^{16}$ Mishnah menggunakan bahasa Ibrani yang biasa disebut 
Mishnaic Hebrew. Mishnaic Hebrew adalah pengembangan langsung bahasa Ibrani dalam kehidupan sehari-hari dari periode terakhir Perjanjian Lama, yang sudah banyak bercampur dan berada di bawah pengaruh bahasa Aram ${ }^{17}$. Pengaruh bahasa Aram dalam bahasa Ibrani menjadi kuat saat masa post-pembuangan dan setelahnya karena keberadaan bahasa Aram yang menjadi bahasa Internasional di dunia Timur Tengah kuno saat itu. ${ }^{18}$ Karenanya diperkirakan bahwa kitab Pengkhotbah ditulis setelah periode orang-orang Yahudi kembali dari pembuangan.

Kedua, meski ditulis dengan menggunakan bahasa Ibrani dengan pengaruh kuat bahasa Aram, juga ditemukannya pengaruh ejaan Fenisia di dalamnya, ${ }^{19}$ dan ditemukannya dua kata pinjaman bahasa Persia, dalam kitab Pengkhotbah tidak ditemukan kata-kata Yunani serta konstruksi bahasa Yunani. Tidak adanya konstruksi bahasa Yunani dalam Kitab Pengkhotbah menuntun para ahli pada kesimpulan bahwa Kitab Pengkhotbah disusun pada akhir dominasi kekaisaran bangsa Persia atau awal periode kekaisaran Yunani, yaitu akhir abad ke-4 SM atau awal abad ke-3 SM. ${ }^{20} \mathrm{Hal}$ ini dikuatkan dalam Kitab Pengkhotbah ditemukan keterangan tentang hierarki pegawai pemerintahan di sebuah propinsi di bawah kekuasaan raja yang 'jauh' (Pkh. 5:7) dan tentang sebuah kekuasaan lokal lain selain kekuasaan raja yang jauh itu (Pkh. 10:5). ${ }^{21}$

Meski secara politis orang-orang Yahudi tidak merasa terancam dengan pemerintah penjajah Yunani-Mesir, secara kultural orangorang Yahudi (terutama kaum ortodoks) tidak merasa nyaman dengan penyebaran budaya Yunani (helenisasi) yang menyelimuti mereka (bangsa Yahudi). Hal ini diperkuat dengan fenomena banyaknya orang Yahudi, khususnya kaum mudanya yang tertarik mengikuti gaya hidup dan kebudayaan Yunani, serta meninggalkan adat istiadat Yahudi dan praktik keagamaannya. ${ }^{22}$ Pemerintah Yunani sendiri senantiasa mempopulerkan budaya helenisme kepada masyarakat jajahannya. ${ }^{23}$ Jika dikaitkan dengan situasi sosial yang demikian, Kitab Pengkhotbah tampaknya sengaja dihadirkan oleh penulisnya untuk mengembangkan sikap kritis orang Yahudi, khususnya kaum mudanya. Dalam hal ini dengan berani "menguji segala sesuatu di bawah matahari" - sebagaimana metode filosofis yang ditunjukkan dalam kitab ini - pembaca pun diharapkan mampu menilai apa yang 'baik' (berfaedah, berguna) dan apa yang 'buruk' (tidak berfaedah, tidak berguna) pada masing-masing budaya, baik kebudayaan Yunani atau 
kebudayaan Yahudi; menyerap yang baik dan membuang yang buruk, baik yang berasal di kebudayaan Yunani atau Yahudi, sehingga menjadi manusia yang memiliki pegangan hidup yang mantap. ${ }^{24}$

\section{Tempat Penulisan Kitab Pengkhotbah}

R.B.Y Scott menjelaskan dari warna dialek bahasa Aram dan bahasa Fenisia dalam kitab, pengarang Pengkhotbah nampaknya telah memiliki hubungan dengan bangsa Fenisia atau pernah hidup di daerah perbatasan Israel utara. Hal ini dikuatkan bahwa dari keterangan Kitab Yehezkiel 28:1-19 dan Zakharia 9:2 mengindikasikan bahwa tradisi hikmat tumbuh subur di daerah Tirus (berdekatan dengan wilayah Fenisia). Namun, dari referensi-referensi dalam kitab Pengkhotbah yang menunjukkan fenomena cuaca dalam relasinya dengan aktivitas pertanian (Pkh. 11:3-4; 12:2), konteks wilayah yang ditampilkan lebih mirip kondisi iklim di Palestina daripada bangsa Fenisia yang kondisi airnya sedikit lebih baik, daripada wilayah Palestina. ${ }^{25}$

Bukti lain bahwa kitab Pengkhotbah ditulis di Palestina, juga ditunjukkan dengan pengetahuan pengarang tentang "Bait Allah" dan tradisi kudus yang dilangsungkan di dalamnya (Pkh. 4:17). Dari keterangan Pengkhotbah (4:17) keberadaan pengarang tampaknya memang tidak jauh dari Bait Allah, yang artinya masih dalam wilayah Palestina.

\section{Penulis Kitab Pengkhotbah}

Kitab Pengkhotbah dimulai dengan keterangan diri, "Inilah perkataan Pengkhotbah, anak Daud, raja di Yerusalem...” (Pkh. 1:1). Keterangan ini diperjelas dalam Pkh. 1:12-13: "Aku, Pengkhotbah, adalah raja atas Israel di Yerusalem. Aku membulatkan hatiku untuk memeriksa dan menyelidiki dengan segala hikmat..." Dua keterangan ini dapat menggiring pembaca pada dua kesimpulan. Pertama, judul kitab ini ('Pengkhotbah') tidak lain menunjuk pada pengarang kitab, yaitu 'pengkhotbah' sendiri. Kedua, Siapakah 'pengkhotbah' itu? Jawabannya adalah Raja Salomo (anak Daud, raja di Yerusalem). Dikaitkan dengan bukti linguistik yang ada, kesimpulan ini mungkin bukanlah kesimpulan yang tepat karena Raja Salomo hidup jauh sebelum abad ke-4 atau ke-3 SM.

Perlu diperhatikan bahwa dalam kitab ini pengarang menghadirkan dirinya secara "tidak konsisten". Dalam hal ini, pada satu bagian, pengarang 
menggunakan kata ganti orang pertama, 'aku' ('aku' = 'pengkhotbah') - dan ini yang paling sering digunakan pengarang. Namun, di beberapa bagian lain pengarang menggunakan kata ganti 'dia' ('dia' = pengkhotbah). Dalam gaya 'aku', pengarang menunjukkan bahwa dirinya sendirilah penulis kitab ini, sekaligus yang terlibat (yang mengalami) berbagai peristiwa yang ia ceritakan dalam kitab ini (contohnya, Pkh. 1:12-14).

"Aku, Pengkhotbah, adalah raja atas Israel di Yerusalem. Aku membulatkan hatiku untuk memeriksa dan menyelidiki dengan segala hikmat segala yang terjadi di bawah langit. Itu pekerjaan yang menyusahkan yang diberikan Allah kepada anak-anak manusia untuk melelahkan diri. Aku telah melihat segala perbuatan yang dilakukan orang di bawah matahari, tetapi lihatlah, segala sesuatu adalah kesiasiaan dan usaha menjaring angin."

Namun pada bagian lain, pengarang juga menggunakan kata ganti 'dia' (= 'pengkhotbah') untuk menunjukkan bukan 'aku' (pengarang) yang mengalami berbagai peristiwa dalam kitab, tetapi dia ('pengkhotbah'). Pengarang hanya menyampaikan apa yang dialami atau dikatakan oleh dia (= 'pengkhotbah'). Hal ini ditunjukkan pada bagian awal kitab, 'Inilah perkataan Pengkhotbah, anal Daud, raja Yerusalem. Kesia-siaan belaka, kata Pengkhotbah, kesia-siaan belaka, segala sesuatu adalah sia-sia" (Pkh. 1:1-2). Hal serupa juga ditampilkan dalam epilog kitab ini: "Selain Pengkhotbah berhikmat, ia mengajarkan juga kepada umat itu pengetahuan. Ia menimbang, menguji, dan menyusun banyak amsal” (Pkh. 12:9). Di bagian lain, pengarang juga menampilkan diri 'aku' yang adalah 'dia'. Dalam hal ini, pengarang masih menggunakan sudut pandang penulisan 'dia' dalam menghadirkan dirinya dalam kitab yang, pada awalnya pengarang mengggunakan kata ganti orang pertama. ${ }^{26}$ Contohnya, "Lihatlah, ini yang ku-dapati, kata Pengkhotbah: Sementara menyatukan yang satu dengan yang lain untuk mendapat kesimpulan, ..." (Pkh. 7:27).

Dari bukti ini dapat ditemukan bahwa penamaan kitab ini sebagai 'Qoheleth' (= 'guru kebijaksanaan yang mengumpulkan dan mengajar umat"), tidak serta merta menunjuk pada pengarang kitab. Penulis kitab Pengkhotbah adalah anonim (tak diketahui). Mungkin dia adalah salah satu guru kebijaksanaan di Yerusalem, mungkin juga orang lain (muridnya) yang terlibat dalam kepengarangan kitab, ${ }^{27}$ sehingga Kitab Pengkhotbah bukanlah karya penulis tunggal. Yang bisa disimpulkan adalah penamaan 
kitab sebagai Qobeleth lebih dimaksudkan untuk menunjukkan 'karakter' kitab ini, daripada menunjuk siapa pengarang kitabnya. Dalam hal ini, sipapun penulisnya, pengarang kitab ini berbicara atas nama 'Qoheleth' (guru kebijaksanaan Israel) agar pengajaran hikmatnya diterima pembaca sebagai pengajaran hikmat ilahi. ${ }^{28}$

Dengan demikian asosiasi pengarang dengan Raja Salomo adalah juga demi meyakinkan pembaca. Dalam hal ini dengan mengasosiasikan apa yang dikatakan (diajarkan) dalam kitab adalah berasal dari Salomo, hendak disampaikan bahwa hikmat yang diajarkannya adalah kebenaran mendalam, hikmat ilahi dari Allah. Dalam dunia kesusastraan Timur'Tengah kuno, metode penulisan dengan mengaitkan pernyataan pengarang dengan tokoh kebijaksanaan populer di negeri itu adalah sebuah literary convention ${ }^{29}$ yang lazim. Metode penulisan ini berbeda dengan metode penulisan karyakarya sastra modern yang lebih menunjukkan orisinalitas pengarang. ${ }^{30}$

\section{Kekhasan Kitab Pengkhotbah}

\section{Buku Filsafat daripada Kitab Suci?}

Pengkhotbah adalah kitab yang 'ganjil' dalam Kitab Suci, dari sekian banyak daftar kitab (kanon) Yahudi dan Kristen. Salah satu faktor yang menyebabkan pembaca merasakan keanehan atas kitab ini adalah bahwa kitab ini lebih mirip buku filsafat daripada Kitab Suci. Pengarang kitab ini mencoba mencari pemahaman rasional terkait eksistensi manusia. Dengan menggunakan identitas "raja Israel di Yerusalem", pengarang Pengkhotbah mencoba mencari makna kehidupan yang tahan uji (Pkh. 1:12-13). Berawal dari pertanyaan, "Apa yang berharga dan perlu dilakukan manusia di bawah matahari?” (Pkh. 1:3) pengarang pun mencari makna kehidupan dengan menampilkan alasan manusiawi dan data yang dapat diamati, serta mengujinya. Dalam hal ini pengarang mengesampingkan "data spesial" terkait "agama wahyu" bahwa Allah adalah Yahweh dan Ia telah mewahyukan diriNya kepada manusia, melalui bangsa Israel sebagai bangsa terpilih. ${ }^{31}$

Terkait pencarian filosofis pengarang Pengkhotbah akan makna kehidupan, pengarang menggunakan metode filosofis yang cukup unik. Dalam hal ini "metode filosofis" yang digunakan pengarang tidak dimulai dari argumen logis yang berkembang selangkah demi selangkah 
menuju kesimpulan, tapi dari sebuah tesis awal, "Kesia-siaan belaka, kata Pengkhotbah, kesia-siaan belaka, segala sesuatu adalah sia-sia" (Pkh. 1:2). Dari tesis ini, pengarang kemudian menganalisis berbagai macam pengalaman yang membawanya pada kesimpulan. Pengarang membagikan refleksinya tentang ketidakmampuan manusia untuk mengetahui Allah. Pengarang juga memperbesar ‘kekosongan’ dan ketidakmampuan usaha manusia untuk mendapatkan segala sesuatu yang berharga dalam masa hidupnya yang singkat (Pkh. 1:15 - 2:23), dan dari sini pengarang beralih ke pertanyaan, "Bagaimana manusia seharusnya mengarahkan hidupnya, di bawah kondisi-kondisi keras eksistensinya?"

Pengarang Pengkhotbah juga membuat afirmasi positif dalam filsafatnya bahwa tidak ada yang lebih baik bagi manusia selain menikmati "keadaan tetap hidup" (being alive) (Pkh. 2:24). Kehidupan seharusnya dinikmati, sejauh Allah yang tidak dipahami manusia mengizinkannya, dengan selalu disertai sikap tidak berlebihan dan hati-hati. Oleh karenanya, Pengkhotbah pun memberikan nasihat bahwa masa muda seharusnya dinikmati sebagai masa yang paling bersemangat dalam hidup, yang sebisa mungkin tidak diganggu oleh rasa sakit atau kelemahan.

"Bersukarialah, hai pemuda, dalam kemudaanmu, biarlah hatimu bersuka pada masa mudamu, dan turutilah keinginan hatimu dan pandangan matamu, tetapi ketahuilah bahwa karena segala hal ini Allah akan membawa engkau ke pengadilan! Buanglah kesedihan dari hatimu dan jauhkanlah penderitaan dari tubuhmu, karena kemudaan dan fajar hidup adalah kesia-siaan" (Pkh. 11:9-10).

Menyadari kehidupan manusia yang singkat dan berlalu begitu cepat, terkurung dalam jalan singkat menuju "kegelapan akhir" (kematian), pengarang pun mengulangi lagi tesisnya, "kesia-siaan atas kesia-siaan, segala sesuatu adalah sia-sia" (Pkh. 12:8). ${ }^{32}$ Dengan kata lain, pengujian pengarang atas berbagai pengalaman, selalu membawanya pada kesimpulan, "segala sesuatu adalah kesia-siaan dan usaha menjaring angin" (Pkh. 1:14; bdk. Pkh. 2:11,17, 21,26). ${ }^{33}$

\section{Pengarub Pemikiran Yunani, Timur Tengah, atau Yabudi?}

Dari cara penyampaian gagasannya yang filosofis, pembaca dapat bertanya-tanya, "Apakah ada pengaruh pemikiran Yunani dalam kitab ini?" apalagi jika dikaitkan dengan waktu penulisan kitab, yaitu sekitar akhir 
abad ke-4, menjelang abad ke-3 SM, ketika budaya Helenisme disebarkan ke seluruh dunia. Terkait hal ini muncul beragam pendapat.

Scott berpendapat kemiripan pemikiran Pengkhotbah dengan ide-ide filsafat Yunani bisa disebabkan karena pengarang Pengkhotbah (diduga) telah memiliki hubungan dengan guru-guru kebijaksanaan lain (nonisrael) di kota-kota pelabuhan bangsa Fenisia atau mungkin telah mengunjunginya. Perlu diketahui pula bahwa sebelum Aleksader Agung melakukan penaklukan atas bangsa Fenisia ( \pm 332 SM), ide-ide filsafat Yunani telah menjadi pembicaraan umum di kota-kota pelabuhan Fenisia. Pengarang Pengkhotbah tampaknya telah terlibat dalam diskusi dan pembicaraan umum diantara orang-orang atau guru-guru kebijaksanaan nonisrael zaman itu. Hal ini dikuatkan bahwa nada kekecewaan yang rumit dalam kitab Pengkhotbah mengingatkan pembaca akan atmosfer kehidupan kosmopolitan di kota-kota pelabuhan, daripada kota provinsi pedalaman seperti di Yerusalem. ${ }^{34}$

Namun, ada pula yang menduga bahwa Kitab Pengkhotbah memiliki karakter filosofis yang tidak bisa disamakan dengan ajaran-ajaran filosofis dari sekolah-sekolah kebijaksanaan Yunani. ${ }^{35}$ Dalam hal ini gagasan yang ditampilkan dalam kitab Pengkhotbah tetap berakar mendalam pada prinsip dasar pemikiran Yahudi, tetapi penulis juga dipengaruhi oleh sikap skeptik dan pesimistik sastra kebijaksanaan Mesopotamia. ${ }^{36}$ Pemikiran Yahudi yang menjadi 'pegangan' adalah eksistensi riil dari satu Allah dan kedaulatanNya atas seluruh ciptaan (alam dan manusia). Bagi Pengkhotbah, hal ini adalah misteri transendensi yang tidak bisa ditolak, sebagaimana juga ditekankan dalam kitab Para Nabi dan Hukum Taurat. Namun pengarang Pengkhotbah tidak berpikir bahwa kenyataan penciptaan alam semesta menandakan lahirnya relasi Allah dengan manusia dalam waktu historis, secara khusus terkait pewahyuan Allah terhadap bangsa Israel sebagai bangsa pilihan Allah.

Hal inilah yang membedakan kitab Pengkhotbah dengan kitab para nabi juga kitab-kitab Taurat. Hukum Taurat dan Kitab Para Nabi telah menyatakan bahwa Allah adalah pencipta yang mahakuasa. Bagi bangsa Israel, hal ini tidak sekadar diketahui, tetapi juga dialami, bahwa Allah telah berbicara kepada manusia melalui perantaraan Musa dan para nabi. Ia telah menyatakan kehendak-Nya dan kuasa-Nya dalam peristiwa-peristiwa sejarah dalam hidup umat pilihan-Nya, Israel. Dengan demikian kisah 
'penciptaan' dalam Kitab Suci pun dimaknai sebagai dimulainya relasirelasi Allah dengan bangsa Israel dalam sejarah manusia. ${ }^{37}$

Gagasan teologis ini tidak berlaku dalam kitab Pengkhotbah. Dalam kitab Pengkhotbah 'penciptaan' bermakna sederhana, yaitu terbentuknya pada awal mula hal-hal fisis (alam semesta) yang tak dapat diubah lagi dan penempatan sementara kehidupan generasi manusia yang terus berlanjut ("All the world's a stage,/ And all the men and women merely players (seluruh dunia adalah sebuah panggung,/ Dan semua laki-laki dan perempuan sekadar pemain-pemain).” Dengan demikian bagi Pengkhotbah doktrin divine providence (pemeliharaan Allah yang baik dan tak terbatas) bersifat 'sewenang-wenang' terserah Allah. Dalam hal ini apa yang Allah sedang kerjakan adalah dalam rahasia-Nya. Dia mengatur dengan baik atau buruk, dan manusia tidak dapat mengetahuinya. Bagi Pengkhotbah fakta 'pewahyuan', bahwa Allah telah menyatakan kehendak-Nya melalui perantaraan Musa dan para Nabi, secara khusus kepada bangsa Israel, dikesampingken karena tidak ada kemungkinan komunikasi manusia dengan Allah (Pkh. 3:11). ${ }^{38}$

\section{Kematian Bukanlah Akhir Kebidupan}

Kekhasan lain dari kitab ini adalah gagasannya tentang kematian. Pengkhotbah 3:19-20 menuliskan,

"Karena nasib manusia adalah sama dengan nasib binatang, nasib yang sama menimpa mereka; sebagaimana yang satu mati, demikian juga yang lain. Kedua-duanya mempunyai nafas yang sama, dan manusia tak mempunyai kelebihan atas binatang, karena segala sesuatu adalah sia-sia. Kedua-duanya menuju satu tempat; kedua-duanya terjadi dari debu dan kedua-duanya kembali kepada debu. Siapakah yang mengetahui, apakah nafas manusia naik ke atas dan nafas binatang turun ke bawah bumi." (Pkh. 3:19-20)

Pengkhotbah tidak menganggapnya kematian adalah "akhir kehidupan.”, tapi bukan berarti pula setelah kematian 'kehidupan’ masih berlanjut. Pengarang Pengkhotbah berpendapat setelah mati, manusia memasuki "dunia orang mati" (realm of the dead) dalam rumah kegelapan di mana dirinya hanyalah 'bayangan' dari dirinya sendiri. ${ }^{39}$ Hal ini tidak berarti setelah mati, manusia menjadi ‘setengah' dari dirinya saat ia hidup. Kitab ini mengemukakan saat manusia mati, ia tetap menjadi dirinya seutuhnya. Perbedaannya, ketika manusia memasuki "dunia orang mati”, 
ia menjalani hidup "tanpa guna" (vegetate), yang artinya ia tidak lebih 'hidup' dibandingkan ketika ia masih hidup karena ia masuk ke dalam sheol ("rumah kegelapan", underworld atau "dunia orang mati"). ${ }^{40}$ Dalam sheol manusia menjalani keberadaan orang mati, yang berbeda dengan saat ia masih hidup di dunia (the living person). ${ }^{41}$ Dengan kata lain, kitab ini ingin menegaskan bahwa situasi manusia setelah kematian adalah tidak pasti. Jiwa manusia memang tidak berakhir, tetapi keberadaannya juga hampir tidak ada (almost nonexistence) (Pkh. 9:10. ${ }^{42}$

Akhirnya, Pengkhotbah pun berkesimpulan bahwa kematian adalah peristiwa 'pelupaan' (oblivion) yang mengakhiri kesadaran hidup manusia dan semua kemungkinannya menikmati kenikmatan emosional sesaat di dunia ini. Karena gambaran 'gelapnya' dunia orang mati (sheol), Pengkhotbah mengusulkan agar manusia menggenggam kenikmatan hidup yang cepat berlalu selama manusia masih di dunia. Di sisi lain cara ini adalah versi Pengkhotbah membangun kualitas penerimaan hidup dari sudut pandang pemikiran religius Yahudi. ${ }^{43}$

\section{Pesan Pokok Pengkhotbah: Segala Sesuatu adalah Sia-Sia}

Inilah pesan pokok Pengkhotbah: "Kesia-siaan atas kesia-sian, segala sesuatu adalah sia-sia." Pesan ini muncul berulang-ulang dalam frase-frase serupa, "segala sesuatu adalah kesia-siaan dan usaha menjaring angin" dan "ini pun kesia-siaan”. Kata 'sia-sia' berasal dari kata Ibrani Hebel yang secara harafiah dalam bahasa Inggris berarti breath atau vapor. Kata vapor (hebel atau breath) menunjuk sesuatu yang tampaknya bisa diketahui, tetapi tidak substansial (empty), sementara (transient), dan tidak menguntungkan (worthless). Penerjemahan atas kata ini pun bervariasi untuk menunjukkan berbagai corak kata ini dalam konteks yang berbeda-beda. Terjemahan tradisional menjadi, "Vanity of vanities, all is vanity" (kesia-siaan atas kesia-sian, segala sesuatu adalah sia-sia), yang dapat dimaknai: "Segala sesuatu dalam kehidupan adalah palsu (bollow) dan sepenuhnya sia-sia; cepat berlalu seperti, dan sama saja dengan tidak ada". Dengan kata lain, kesadaran eksistensi manusia -pengalaman perjuangan hidupnya, dan semua usahanya untuk menyelesaikan sesuatu, berakhir menjadi hembusan nafas belaka. Pkh. 1:3 mengatakan, "Apakah gunanya manusia berusaha dengan jerih payah di bawah matahari?" Jawabannya, "Kesia-siaan atas kesia-sian, segala sesuatu adalah sia-sia." Kata hebel (= breath, vapor, sia-sia) 
adalah kata favorit, muncul tiga puluh lima kali dalam kitab Pengkhotbah. ${ }^{44}$

Pengkhotbah menampilkan bukti-bukti atas "apa yang menjadikan segala sesuatu di dunia ini sia-sia."

Pertama, dunia yang adalah tempat kehidupan dan pengalaman hidup manusia menunjukkan pergerakan tak habis-habisnya tanpa perubahan. Aliran yang terus-menerus (perpetual touring) keluar dari usaha tanpa yitrōn, profit (keuntungan). Segalanya dicapai dengan cara ini. Generasi ke generasi datang dan pergi. Umat manusia bergerak melintasi panggung, dari kegelapan menuju kegelapan dalam prosesi yang tak berakhir, ketika panggung itu sendiri berputar dan berputar. Di mana-mana konstan. Pergerakan kehidupan yang membosankan, tapi bukan perubahan yang sesungguhnya. Pengkhotbah pun berpendapat tidak ada yang baru, tidak ada peristiwa baru, dan tidak ada yang dapat diingat. ${ }^{45}$

Apakah gunanya manusia berusaha dengan jerih payah di bawah matahari? Keturunan yang satu pergi dan keturunan yang lain datang, tetapi bumi tetap ada. Matahari terbit, matahari terbenam, lalu terburuburu menuju tempat ia terbit kembali. Angin bertiup ke selatan, lalu berputar ke utara, terus-menerus ia berputar, dan dalam putarannya angin itu kembali. Semua sungai mengalir ke laut, tetapi laut tidak juga menjadi penuh; ke mana sungai mengalir, ke situ sungai mengalir selalu. Segala sesuatu menjemukan, sehingga tak terkatakan oleh manusia; mata tidak kenyang melihat, telinga tidak puas mendengar. Apa yang pernah ada akan ada lagi, dan apa yang pernah dibuat akan dibuat lagi; tak ada sesuatu yang baru di bawah matahari. Adakah sesuatu yang dapat dikatakan: "Lihatlah, ini baru!'? Tetapi itu sudah ada dulu, lama sebelum kita ada. Kenang-kenangan dari masa lampau tidak ada, dan dari masa depan yang masih akan datang pun tidak akan ada kenang-kenangan pada mereka yang hidup sesudahnya'. (Pkh. 1:3-11)

Pengkhotbah mengemukakan alasan untuk hal di atas adalah karena Allah telah menetapkannya, sehingga 'dunia' dari sudut pandang manusia akan selalu menjadi teka-teki yang dapat 'berbelok [bengkok]' tanpa dapat diluruskan lagi (Pkh. 1:15; 7:13). Segala sesuatu yang terjadi atas manusia muncul karena ditetapkan sebelumnya ('dikodratkan'; predetermined) dan dicocokkan dengan saat yang 'tepat' (its appropriate time) dan unik (Pkh. 3:115; 7:23-24; 8:16-17; 9:11-12). Dengan kata lain, Pengkhotbah berpendapat Allah sesungguhnya telah meletakkan sebuah teka-teki yang tidak dapat dipecahkan (an insoluble enigma), sebuah kegelapan dalam pikiran manusia (Pkh. 3:11) dan manusia tidak dalam posisi membantah dengan segala kekuatannya (Pkh. 6:10-12; 7:13). 
Kedua, Pengkhotbah telah membimbing pengalaman-pengalaman pribadinya untuk menemukan rahasia dari apa yang sedang terjadi, tapi semua tidak berbuah. Semua jerih payahnya memiliki hasil yang tidak nyata. Pengkhotbah pun menggenggam "udara yang kosong" ("usaha menjaring angin" [Pkh. 1:12-14]). Tidak hanya itu, ketika Pengkhotbah mencoba untuk menemukan kodrat (nature) kebijaksanan dan apa yang membedakannya dari kebodohan, semua usahanya ini pun 'sia-sia' (Pkh. 1:17-18; 7:23-8:1). Pengkhotbah pun mencari kebijaksanan melalui rasionalitasnya untuk memisahkan dan memberi definisi atas 'kebaikan' (the good) yang berasal dari kesenangan (pleasure) dan kepemilikan (possessions). Pengkhotbah pun menemukan kebahagiaan yang berlangsung hanya sekejap dari momenmomen yang lewat (Pkh. 2:1-11; 5:18); meski setelah menemukannya, nilai kebijaksanaan dan buah usaha manusia itu sama-sama dibatalkan oleh fakta kematian yang tidak dapat ditawar (Pkh. 2:14-16, 18-26; 5:10-16). ${ }^{46}$

Ketiga, Pengkhotbah berpendapat bahwa pandangan teologis yang menganggap bahwa ganti rugi pasti menyusul kejahatan, dan kebaikan membawa kecukupan (prosperity) sudah disangkal dalam pengalaman (Pkh. 3:16; 7:15; 8:14). Karakter dan hikmat manusia tampaknya tidak membuat adanya perbedaan takdir bagi siapa saja. Dalam hal ini takdir orang benar dan orang jahat; orang bijaksana dan orang bodoh kurang lebih sama. Mereka sama-sama bertemu dengan ajal yang makin lama makin dekat dan tak dapat dielakkan. Tak seorang pun dapat menjamin apakah Allah akan 'menolongnya' tidak. 'Sesungguhnya, semua ini telah kuperhatikan, semua ini telah kuperiksa, yakni bahwa orang-orang yang benar dan orang-orang yang berhikmat dan perbuatan-perbuatan mereka, baik kasih maupun kebencian, ada di tangan Allah; manusia tidak mengetahui apa pun yang dihadapinya" (Pkh. 9:1).

Dengan kata lain, Pengkhotbah berkesimpulan sesungguhnya manusia dan binatang mati dengan cara yang sama. Tak seorang pun dapat memberi jaminan bahwa jiwa manusia mencapai Allah dan jiwa binatang turun ke bawah bumi.

Tentang anak-anak manusia aku berkata dalam hati: "Allah hendak menguji mereka dan memperlihatkan kepada mereka bahwa mereka hanyalah binatang." Karena nasib manusia adalah sama dengan nasib binatang, nasib yang sama menimpa mereka; sebagaimana yang satu mati, demikian juga yang lain. Kedua-duanya mempunyai nafas yang 
sama, dan manusia tak mempunyai kelebihan atas binatang, karena segala sesuatu adalah sia-sia. Kedua-duanya menuju satu tempat; kedua-duanya terjadi dari debu dan kedua-duanya kembali kepada debu. Siapakah yang mengetahui, apakah nafas manusia naik ke atas dan nafas binatang turun ke bawah bumi. (Pkh. 3:18-21)

Keempat, sebagaimana kehidupan dibatalkan oleh kematian, semua nilai atau keutamaan pun 'dibatalkan' oleh hal-hal sebaliknya. Hal ini ditunjukkan dalam beberapa pernyataan. Misalnya, pengetahuan hanya membawa lebih banyak kesukaran (Pkh. 1:18). Setiap keunggulan diatasi oleh beberapa ketidakberuntungan yang sudah ditetapkan (Pkh. 9:1112). Ketidakacuhan yang lain terhadap hal yang berharga (worth) dan kebijaksanaan (wisdom) membuat ketidakbergunaan ini (Pkh. 9:13-16) dan "sebuah kebodohan kecil mungkin lebih besar daripada kebijaksanaan dan kehormatan" (Pkh. 10:1). Kekuasaan yang sewenang-wenang di tangan manusia pun menempatkan malapetaka bersama nilai-nilai sosial (Pkh. 10:5-7). Orang terkenal segera dilupakan (Pkh. 4:13-16) dan buah-buah dari kerja-keras seumur hidup dan keinginan (anxiety), mungkin bisa hilang hanya karena sebuah kesalahan dalam mempertimbangkan dan mengambil keputusan (Pkh. 5:12-16). Akhinya, kematian adalah akhir dan negasi universal dari nilai-nilai (Pkh. 2:16; 6:6; 8:8; 9:3; 12:1-7).

\section{Apa yang Diajarkan Pengkhotbah dari 'Kesia-siaan'?}

Meski bertema pokok 'kesia-siaan', menolak kehidupan dan melakukan penghancuran diri sendiri bukanlah kesimpulan praktis yang diambil Pengkhotbah. Pengkhotbah menerima segala alasan yang membimbingnya menuju 'kesia-siaan' kehidupan, tetapi pengarang tidak menyarankan pembacanya untuk menjalani hidup ini dengan siasia. Pengkhotbah menawarkan beberapa kebijaksanaan etis, bagaimana seharusnya manusia menjalani hidupnya, jika segala usahanya untuk memaknai kehidupan adalah 'sia-sia' belaka; usaha menjaring angin. Ada beberapa eksplorasi.

Pertama, manusia harus berani menghadapi kenyataan, tetapi harus selalu dengan sikap: jangan terus langsung menerima sesuatu sebagai yang benar; sebelum diuji, dibuktikan dengan fakta yang 'terang-benderang'. Pengkhotbah membuktikan pengajaran tradisional yang menyatakan bahwa kebaikan atau kebajikan (virtue) selalu mendapat hadiah dan sifat buruk selalu mendapat hukuman (Pkh. 8:14) tidaklah selalu benar (bdk. 
Ams 13:6). Pengkhotbah menyatakan, bahwa usaha untuk mencari kebijaksanaan dan keutamaan (virtue), kerja keras untuk menjadi 'kaya' adalah untuk 'menambahkan' kebahagiaan itu sendiri; bukan untuk mendapatkan imbalan (reward) dari kerja keras itu sendiri.

Kedua, Seseorang harus belajar untuk hidup dengan apa yang tidak dapat diubah dan tunduk pada hal-hal yang tak dapat dielakkan. Apa yang bengkok tidak dapat diluruskan oleh usaha manusia dan apa yang salah tidak dapat dibenarkan (Pkh. 1:15). Pada poin ini pengarang Pengkhotbah menasihatkan kepada para pembacanya agar hidup dalam kepatuhan (ketundukan) atas ketetapan Allah yang misterius. "Apakah Allah itu? Apakah urusan-Nya, pekerjaan-Nya? Dan apakah Dia menerima manusia atau tidak?" adalah dalam rahasia-Nya. Hal ini tentu sebuah penolakan terhadap pewahyuan ilahi, tentang keyakinan bahwa manusia diciptakan sebagai sebuah keberadaan yang "hampir ilahi" yang dipercaya untuk memelihara dan menjalankan 'kekuasaan' atas ciptaanciptaan lain dan semua karya dari tangan Allah (Mzm. 8:6-9; Kej 1:26). Namun bagi Pengkhotbah manusia terlalu 'dibatasi' (oleh Allah), baik dalam kebijaksanaannya ataupun kekuatannya, dalam mengerjakan halhal di atas. Semua usaha manusia untuk mentransendensikan eksistensinya melalui kebijaksanaan atau usaha kreatifnya 'dihukum' menuju kekalahan sejak awalnya karena Allah telah menetapkannya. ${ }^{47}$

Ketiga, Pengkhotbah menambahkan sebuah nilai fundamental yang berlaku sama, yaitu kapasitas untuk menemukan enjoyment (kegembiraan; 'kenikmatan') dalam kerja, kebijaksanaan serta dalam setiap pengalaman kehidupan. Dengan kata lain Pengkhotbah ingin mengatakan, "Terimalah kebahagiaan yang dapat menjadi milikmu ketika kamu menyadari bahwa kamu tidak dapat membengkokkan dunia kepada kehendakmu! Jangan melewatkan kebahagiaan saat ini yang harus dicecap, yang dapat dinikmati dalam masa-masa yang sekarang sedang berjalan, atau kebahagiaan itu akan menjadi hilang selamanya! Jangan menyerahkan kesempatanmu untuk menikmati kebahagiaan melalui sebuah 'ketidakpuasan yang resah' yang merupakan ketegangan selamanya atas apa yang tidak dapat kamu miliki (Pkh. 2:24-25, 3:12-14; 9:7-10; 11:7-10)! Namun sadarilah jika Allah mengizinkan menikmati kepenuhan hasrat-hasratmu, hal itu adalah keberuntungan bagimu; yang tidak harus diharapkan sehingga kamu akan mengapresiasinya ketika keberuntungan itu datang." ${ }^{48}$ 
Dengan demikian bagi Pengkhotbah kehidupan tidak pernah menjadi lebih 'manis' ketika seseorang masih muda dengan kekuatannya. $\mathrm{Hal}$ ini dikarenakan usia tua datang dengan cepat, saat manusia melihat kebelakang dengan penyesalan yang mendalam (anguished regret) akan hidup yang dilewatinya dalam keinginan yang tak tentu dan bermacam-macam, serta ambisi yang tanpa hasil.

"Terang itu menyenangkan dan melihat matahari itu baik bagi mata; oleh sebab itu jikalau orang panjang umurnya, biarlah ia bersukacita di dalamnya, tetapi hendaklah ia ingat akan hari-hari yang gelap, karena banyak jumlahnya. Segala sesuatu yang datang adalah kesia-siaan. Bersukarialah, hai pemuda, dalam kemudaanmu, biarlah hatimu bersuka pada masa mudamu, dan turutilah keinginan hatimu dan pandangan matamu, tetapi ketahuilah bahwa karena segala hal ini Allah akan membawa engkau ke pengadilan! Buanglah kesedihan dari hatimu dan jauhkanlah penderitaan dari tubuhmu, karena kemudaan dan fajar hidup adalah kesia-siaan. Ingatlah akan Penciptamu pada masa mudamu, sebelum tiba hari-hari yang malang dan mendekat tahun-tahun yang kaukatakan: "Tak ada kesenangan bagiku di dalamnya!" (Pkh. 11:7-12:1)

Dengan kata lain, Pengkhotbah ingin mengatakan kebaikan dari kehidupan adalah dalam 'menghidupi' kehidupan itu. Keuntungan dari bekerja adalah dalam 'mengerjakannya' dan bukan dalam keuntungannya yang dapat dipamerkan manusia sebagai prestasinya untuk kemudian 'diwariskan' kepada keturunannya. Buah kebijaksanaan bukanlah akumulasi seluruh pengetahuan dan pengertian atas semua misteri, tetapi lebih berupa pengakuan akan batas pengetahuan manusia dan kekuatannya. Dalam hal ini manusia tidak berhak 'mengukur' segala hal. Manusia bukanlah 'tuan' atas kehidupan ataupun kematian. Manusia dapat menemukan ketenangan hanya dalam persetujuannya dengan kondisi-kondisi yang tak dapat diubah dari eksistensinya dan dalam penikmatannya atas hal-hal yang nyata, tapi dengan kepuasan yang terbatas.

\section{Renungan Pengkhotbah akan "Saat yang Indah"}

Dalam terang kebijaksanaan etis di atas akan dipahami misteri waktu yang 'indah' sebagaimana dimaksudkan Pengkhotbah. Oleh karena itu, untuk mencoba memahami perkataan "Ia (Allah) membuat segala sesuatu indah pada waktunya, bahkan Ia memberikan kekekalan dalam hati mereka. Tetapi manusia tidak dapat menyelami pekerjaan yang dilakukan Allah dari awal sampai akhir" (Pkh. 3:1-15), pemikiran Pengkhotbah tentang waktu 
ini perlu diletakkan dalam kesatuan perikop tertentu. Dalam hal ini, saya mengutip pembagian perikop dalam The Anchor Bible, dalam tabel berikut.

Tabel 1 Pembagian Perikop Kitab Pengkhotbah

\begin{tabular}{|c|c|c|}
\hline No. & $\begin{array}{c}\text { Rentang } \\
\text { Ayat }\end{array}$ & Judul Perikop \\
\hline 1 & $1: 1-2$ & $\begin{array}{l}\text { Title of the Book; The Thesis of the Writer } \\
\text { (Judul Kitab; Tesis Pengarang) }\end{array}$ \\
\hline 2 & $1: 3-11$ & $\begin{array}{l}\text { There is Nothing New Under the Sun } \\
\text { (Tidak Ada Sesuatu yang Baru di bawah Matahari) }\end{array}$ \\
\hline 3 & 1:12-18 & $\begin{array}{l}\text { The Futility of Human Effort and Wisdom } \\
\text { (Kesia-sian Usaha Manusia dan Kebijaksanaan) }\end{array}$ \\
\hline 4 & $2: 1-11$ & $\begin{array}{l}\text { The Illusory Satisfactions of Pleasure-Seeking } \\
\text { (Kepuasan yang Ilusif atas Pencarian Kesenangan) }\end{array}$ \\
\hline 5 & $2: 12-17$ & $\begin{array}{l}\text { The Wise Man is no Better off than The Fool } \\
\text { (Orang Bijak Tidak Lebih Baik daripada Orang Bodoh) }\end{array}$ \\
\hline 6 & $2: 18-26$ & $\begin{array}{l}\text { Death Robs A Man of the Fruits of His Labor } \\
\text { (Kematian Merampas Manusia dari Hasil Kerjanya) }\end{array}$ \\
\hline 7 & $3: 1-15$ & $\begin{array}{l}\text { Everything Happens at The Time God Decrees for it } \\
\text { (Segala Sesuatu Terjadi pada Waktu Allah Menetapkannya) }\end{array}$ \\
\hline 8 & $3: 16-4: 3$ & $\begin{array}{l}\text { The Fact of Injustice Proves that Man is only A Mortal Animal } \\
\text { (Fakta Ketidakadilan Membuktikan bahwa Manusia hanya } \\
\text { Binatang yang Fana) }\end{array}$ \\
\hline 9 & $4: 4-16$ & $\begin{array}{l}\text { A Life of Sheer Toil is Profitless } \\
\text { (Kehidupan tentang Kerja Keras yang Tidak Menguntungkan) }\end{array}$ \\
\hline 10 & $\begin{array}{l}4: 17-5: 6 / \\
5: 1-7\left(E V^{49}\right) \\
\end{array}$ & $\begin{array}{l}\text { Advice About Religious Observances } \\
\text { (Nasihat tentang Ketaatan Religius) }\end{array}$ \\
\hline 11 & $\begin{array}{l}5: 7-8 / \\
5: 8-9(E V)\end{array}$ & $\begin{array}{l}\text { The Hierarchy of Exploiters } \\
\text { (Hirarki Penguasa) }\end{array}$ \\
\hline 12 & $\begin{array}{l}\text { 5:9-19 } \\
5: 10-20(E V)\end{array}$ & $\begin{array}{l}\text { Wrong and Right Attitudes to Wealth } \\
\text { (Sikap yang Salah dan Benar atas Kemakmuran) }\end{array}$ \\
\hline 13 & $6: 1-9$ & $\begin{array}{l}\text { Contentment is Life's Highest Good } \\
\text { (Kepuasan Hati adalah Kebaikan Hidup Tertinggi) }\end{array}$ \\
\hline 14 & $6: 10-12$ & $\begin{array}{l}\text { Man's Life is Both Fated and Incomprehensible } \\
\text { (Hidup Manusia ditakdirkan dan Tidak Dapat Dimengerti) }\end{array}$ \\
\hline 15 & $7: 1-14$ & $\begin{array}{l}\text { Seven Proverbs, With Qobeleth's Comments } \\
\text { (Tujuh Amsal [Pepatah] dengan Komentar Pengkhotbah) }\end{array}$ \\
\hline 16 & $7: 15-22$ & $\begin{array}{l}\text { No Man Can Be Perfect } \\
\text { (Tak Ada Manusia dapat Sempurna) }\end{array}$ \\
\hline 17 & $7: 23-8: 1$ & $\begin{array}{l}\text { The Frustrating Search For Wisdom } \\
\text { (Pencarian Kebijaksanaan yang Membuat Frustrasi) }\end{array}$ \\
\hline
\end{tabular}




\begin{tabular}{|c|l|l|}
\hline 18 & $8: 2-9$ & $\begin{array}{l}\text { Kings Should Be Obeyed Because of Their Power Over Men } \\
\text { (Raja Harus Ditaati Karena Kekuasaan Mereka atas Manusia) }\end{array}$ \\
\hline 19 & $8: 10-15$ & $\begin{array}{l}\text { Wickedness Goes Unpunished in This Life } \\
\text { (Kejahatan Tidak Dihukum dalam Hidup Ini) }\end{array}$ \\
\hline 20 & $8: 16-9: 12$ & $\begin{array}{l}\text { Man's Mysterious Fate } \\
\text { (Takdir Misterius Manusia) }\end{array}$ \\
\hline 21 & $9: 13-10: 1$ & $\begin{array}{l}\text { Pessimism About Wisdom in Practice } \\
\text { (Pesimisme tentang Kebijaksanaan dalam Praktek) }\end{array}$ \\
\hline 22 & $10: 2-11: 6$ & $\begin{array}{l}\text { A Miscellany of Precepts, Proverbs, and Reflections on Life } \\
\text { (Rangkuman Persepsi, Amsal [Pepatah], dan Refleksi-Refleksi atas } \\
\text { Hidup) }\end{array}$ \\
\hline 23 & $11: 7-12: 8$ & $\begin{array}{l}\text { The Joys of Youth and The Onset of Age } \\
\text { (Sukacita Masa Muda dan Serangan Masa Tua) }\end{array}$ \\
\hline 24 & $12: 9-14$ & $\begin{array}{l}\text { Biographical Footnotes and Summation by Another Sage (Catatatan Kaki } \\
\text { Biografis dan Penutup dari Guru Kebijaksanaan yang Lain) }\end{array}$ \\
\hline
\end{tabular}

Berdasarkan tabel di atas, Pengkhotbah (3:11) berada dalam kesatuan perikop Pengkhotbah 3:1-15, yang secara keseluruhan tertulis:

${ }^{1}$ Untuk segala sesuatu ada masanya, untuk apa pun di bawah langit ada waktunya. ${ }^{2}$ Ada waktu untuk lahir, ada waktu untuk meninggal, ada waktu untuk menanam, ada waktu untuk mencabut yang ditanam; ${ }^{3}$ ada waktu untuk membunuh, ada waktu untuk menyembuhkan; ada waktu untuk merombak, ada waktu untuk membangun; ${ }^{4}$ ada waktu untuk menangis, ada waktu untuk tertawa; ada waktu untuk meratap; ada waktu untuk menari; ${ }^{5}$ ada waktu untuk membuang batu, ada waktu untuk mengumpulkan batu; ada waktu untuk memeluk, ada waktu untuk menahan diri dari memeluk; ${ }^{6}$ ada waktu untuk mencari, ada waktu untuk membiarkan rugi; ada waktu untuk menyimpan, ada waktu untuk membuang; ${ }^{7}$ ada waktu untuk merobek, ada waktu untuk menjahit; ada waktu untuk berdiam diri, ada waktu untuk berbicara; ${ }^{8}$ ada waktu untuk mengasihi, ada waktu untuk membenci; ada waktu untuk perang, ada waktu untuk damai. ${ }^{9}$ Apakah untung pekerja dari yang dikerjakannya dengan berjerih payah? ${ }^{10} \mathrm{Aku}$ telah melihat pekerjaan yang diberikan Allah kepada anak-anak manusia untuk melelahkan dirinya. ${ }^{11}$ Ia membuat segala sesuatu indah pada waktunya, bahkan Ia memberikan kekekealan dalam hati merek.a. Tetapi manusia tidak dapat menyelami pekerjaan yang dilakukan Allah dari awal sampai akhir. ${ }^{12} \mathrm{Aku}$ tahu bahwa untuk mereka tak ada yang lebih baik dari pada bersuka-suka dan menikmati kesenangan dalam hidup mereka. ${ }^{13}$ Dan bahwa setiap orang dapat makan, minum dan menikmati kesenangan dalam segala jerih payahnya, itu juga adalah pemberian Allah. 


\begin{abstract}
${ }^{14} \mathrm{Aku}$ tahu bahwa segala sesuatu yang dilakukan Allah akan tetap ada untuk selamanya; itu tak dapat ditambah dan tak dapat dikurangi; Allah berbuat demikian, supaya manusia takut akan Dia. ${ }^{15}$ Yang sekarang ada dulu sudah ada, dan yang akan ada sudah lama ada; dan Allah mencari yang sudah lalu.
\end{abstract}

Dari kutipan perikop di atas, dapat dirumuskan skema gagasan teologis perikop ini sebagai berikut.

Pertama, Pengkhotbah berpendapat dalam perputaran pengalaman manusia yang berlangsung terus menerus, setiap peristiwa terjadi pada waktu yang 'tepat'. Pkh. 3:1 menuliskan, "Untuk segala sesuatu ada masanya, untuk apa pun di bawah langit ada waktunya." Ayat ini mengandaikan kemahakuasaan Tuhan atas waktu dan atas peristiwaperistiwa yang terjadi dalam waktu. Robinson membedakan istilah season dan time. Season menunjuk pada fixed moment. Sedangkan time menunjuk pada occurrence. Dengan demikian, ide yang dapat dimunculkan dari ayat ini adalah peristiwa (occurrence) terjadi ketika hal itu harus terjadi, ada saat yang tepat (an appropriate time) seseorang menyelesaikan tindakan-tindakan tertentu. $^{50}$

Dalam terjemahan berbahasa Inggris versi The Anchor Bible, frasa "segala sesuatu" diterjemahkan menjadi every happening. Kata happening or phenomenon, berasal dari kata dari kata hēpeș (Ibrani) yang bermakna desire, desirable thing (hal yang diinginkan, diperlukan). Dengan demikian, “...there is a proper time for every happening under the sun" (3:1) dapat dimaknai, "ada waktu yang pas untuk segala hal yang diinginkan atau diperlukan" (bdk. Pkh. 3:17; 8:6). Dari sini Pengkhotbah menghadirkan empat belas antitesis, yang terumuskan dalam ayat dua sampai delapan, yang adalah skema Allah atas segala sesuatu.

\footnotetext{
${ }^{2}$ Ada waktu untuk lahir, ada waktu untuk meninggal, ada waktu untuk menanam, ada waktu untuk mencabut yang ditanam; ${ }^{3}$ ada waktu untuk membunuh, ada waktu untuk menyembuhkan; ada waktu untuk merombak, ada waktu untuk membangun; ${ }^{4}$ ada waktu untuk menangis, ada waktu untuk tertawa; ada waktu untuk meratap; ada waktu untuk menari; ${ }^{5}$ ada waktu untuk membuang batu, ada waktu untuk mengumpulkan batu; ada waktu untuk memeluk, ada waktu untuk menahan diri dari memeluk; ${ }^{6}$ ada waktu untuk mencari, ada waktu untuk membiarkan rugi; ada waktu untuk menyimpan, ada waktu untuk membuang;
} 
${ }^{7}$ ada waktu untuk merobek, ada waktu untuk menjahit; ada waktu untuk berdiam diri, ada waktu untuk berbicara; ${ }^{8}$ ada waktu untuk mengasihi, ada waktu untuk membenci; ada waktu untuk perang, ada waktu untuk damai (Pkh. 3:2-8) ${ }^{51}$

Kedua, karena setiap peristiwa berlangsung dalam skema Allah, usaha manusia untuk membuat apa yang terjadi sesuai dengan keinginannya tidak akan akan berhasil atau sia-sia. Hal ini ditunjukkan dalam ayat sembilan (Pkh. 3:9), "Apakah untung pekerja dari yang dikerjakannya dengan berjerih payah?" "What is the profit to the doer in that at which he toils? (Apa keuntungan bagi pekerja dalam kerja keras atau jerih payah yang ia pilih; ia usahakan?)" Segala sesuatu harus terjadi pada saat yang tepat (at the right moment) sesuai dengan rencana Allah, tak ada yang dapat manusia kerjakan untuk menjadi berbeda dengan rencana Allah itu. ${ }^{52}$ Dengan kata lain, struktur umum kehidupan dan waktu tertentu individu yang terkandung didalamnya telah diketahui secara umum, tetapi manusia tidak mengetahui saat khusus (the particular hour) dan tidak pernah yakin akan hasil yang didapatkan dari tindakan-tindakanya. ${ }^{53}$

Ketiga, Pengkhotbah pun menyimpulkan bahwa Allah menjadikan setiap peristiwa 'tepat' pada waktunya, "[and I see too] that God makes each event right for its time." (Pkh. 3:11a). Terjemahan Kitab Suci LAI merumuskannya dengan kata-kata: "Ia membuat segala sesuatu indah pada waktunya,... (3:11a)." Menurut Pengkhotbah segala sesuatu itu terjadi 'tepat' pada waktunya (pada waktu peristiwa itu 'seharusnya' terjadi), karena Allah telah menetapkannya sejak awal (has predetermined), tersembunyi dari manusia. Untuk menggambarkan ketidakmampuan manusia untuk tahu tentang "ketetapan Allah" atas skema segala peristiwa ini, ayat 11b menuliskannya sebagai berikut, “...bahkan Ia (Allah) memberikan kekekalan dalam hati mereka. Tetapi manusia tidak dapat menyelami pekerjaan yang dilakukan Allah dari awal sampai akhir (... Yet he has put in their minds an enigma, so that man cannot discover what it is that God has been doing, from beginning to the end." [Pkh. 3:11b])."

Kata 'kekekalan' dalam kutipan ayat di atas disepadankan dengan kata enigma (dalam terjemahan bahasa Inggris. Kata enigma dalam bahasa Inggris berasosiasi dengan kata benda darkness (kegelapan, kemuraman) atau obscurity (ketidakjelasan, tak dikenal). Dalam bahasa Ibrani kata enigma sepadan dengan kata 'ōlām. Makna akar kata ini adalah that which is hidden (yang tersembuyi; yang disembunyikan), sebagaimana dirumuskan dalam 
frase umum 'ad 'ōlām, yang berarti until the distant (sampai jauh), bidden future (masa depan yang tersembunyi), forever (selalu, selama-lamanya). Dengan kata lain, menurut Pengkhotbah, manusia tidak mengetahui maksudmaksud Allah karena enigma (kekekalan) yang telah diletakkan Allah dalam hatinya. Manusia tidak disanggupkan, disesuaikan (is not geared) dengan skema Allah atas segala sesuatu. Oleh karenanya, "manusia tidak dapat menyelami pekerjaan yang dilakukan Allah dari awal sampai akhir." ${ }^{54}$ Manusia tidak mampu mengerti aktivitas Allah dalam totalitasnya. ${ }^{55}$

Keempat, apa yang bisa dikerjakan manusia adalah hidup dalam kepatuhan (rasa hormat) terhadap gerak maju 'waktu' yang tidak dapat ditawar-tawar, sambil menikmati "kebahagiaan yang lewat" (the passing happiness) sebagaimana Allah merahmatkannya secara 'cukup' dari sudut pandang Allah kepada manusia, sebagaimana dirumuskan dalam 3:12-13:56 "Aku tahu bahwa untuk mereka tak ada yang lebih baik dari pada bersukasuka dan menikmati kesenangan dalam hidup mereka. Dan bahwa setiap orang dapat makan, minum dan menikmati kesenangan dalam segala jerih payahnya, itu juga adalah pemberian Allah.”

Pkh. 3:14 lebih bersifat menegaskan determinisme Allah atas segala sesuatu: "Aku tahu bahwa segala sesuatu yang dilakukan Allah akan tetap ada untuk selamanya; itu tak dapat ditambah dan tak dapat dikurangi; Allah berbuat demikian, supaya manusia takut akan Dia." Rangkaian ayat dalam perikop ini ditutup dengan ayat 15 (Pkh. 3), yang mengandung dua gagasan. Pertama, pemikiran Pengkhotbah (3:15a) mirip dengan pemikiran Stoa tentang peredaran dunia yang terus-menerus dan berulang, "Yang sekarang ada dulu sudah ada, dan yang akan ada sudah lama ada" (Pkh. 3:15a; bdk. Pkh. 1:9). Kedua, Pkh. 3:15b mengandung pesan bahwa segala sesuatu yang ditentukan Allah mencakup secara luas, baik masa lalu (past), saat ini (present) dan masa depan (future). Hal ini menjadi lebih 'jelas' ketika "Allah mencari yang sudah lalu" (Pkh. 3:15b). ${ }^{57}$

\section{Simpulan}

"Segala sesuatu indah pada waktunya" mungkin menjadi kata-kata penghiburan bagi mereka yang mengalami situasi sulit dalam kehidupan, sementara mereka sebagai subjek penderita sudah mengusahakan agar situasi sulit yang saat ini dialami tidak terjadi. Pemaknaan kutipan "segala sesuatu indah pada waktunya" bisa mengecewakan karena orang tidak memahami konteks biblisnya, yaitu dalam Kitab Pengkhotbah (3:11), yang 
secara lengkap: "Ia membuat segala sesuatu indah pada waktunya, bahkan Ia memberikan kekekalan dalam hati mereka. Tetapi manusia tidak dapat menyelami pekerjaan yang dilakukan Allah dari awal sampai akhir."

Dengan memahami kutipan "segala sesuatu indah pada waktunya" dalam keutuhan ayat di atas, berarti dapat disimpulkan dua hal. Pertama, Allah telah mengatur dan menetapkan segala sesuatu dalam kehendakNya dan rencana-Nya dengan baik. Dengan demikian setiap waktu yang dialami manusia, dari sudut pandang Allah adalah 'indah' adanya. Jika tidak demikian, menurut manusia, hal itu tentu bukan 'kesalahan' Allah. Bagi Allah, setiap waktu adalah "saat yang indah", yakni waktu 'perkenanan' ketika Allah menghadirkan diri-Nya dalam kehidupan manusia, di dalam setiap pengalaman manusia.

Kedua, pemaknaan "segala sesuatu indah pada waktunya" mungkin sering kurang lengkap karena pembaca umumnya melupakan kelanjutan bagian itu dalam ayat yang bersangkutan, "Tetapi manusia tidak dapat menyelami pekerjaan yang dilakukan Allah dari awal sampai akhir" (Pkh. 3:11b). Para pengagum ayat ini mungkin 'melupakan' bahwa Allah telah meletakkan 'kekekalan' (enigma) dalam hati manusia yang paling dalam, dan yang menjadikan manusia tidak mampu memahami misteri kehendak Allah dalam totalitas rencana karya keselamatan-Nya (Pkh. 3:11b). Ketiga, dari sini manusia diharapkan menerima segala ketetapan Allah. Hanya dengan cara ini manusia mencapai kedamaian selama hidupnya di dunia ini, karena ia (manusia) tidak sepenuhnya memahami misteri Allah. Dengan menerima pengertian ini, mereka yang menderita pun bisa mengerti bahwa setiap waktu kehidupan manusia adalah "saat yang indah", sebagaimana Allah telah menetapkan bahwa segalanya (setiap saat) adalah 'indah' dalam keseluruhan rencana-Nya.

\section{Bibliography}

Buck., F. "Ecclesiastes". Reginald C. Fuller et al. (eds.). A New Catholic Commentary on Holy Scripture. Hongkong: Thomas Nelson LTD: 512521, 1975.

Ceresko, Anthony R. Introduction to The Old Testament: A Liberation Perspective. Quezon City: Claretian Publications, 1992. 
Douglas, J.D., et al. (eds.). Ensiklopedi Alkitab Masa Kini (Jilid I: A - L). Terj. Yayasan Komunikasi Bina Kasih. Jakarta: Yayasan Komunikasi Bina Kasih, 1995.

Groenen, C. Pengantar ke dalam Perjanjian Lama. Yogyakarta: Kanisius, 1980. Hartman, L.F. "Mishnah". Thomas Carson et al. (eds.). The New Catholic Encyclopedia, Second Edition [Volume 9]. Washington D.C.: The Catholic Universitty of America, 2003.

Hill, Andrew E. \& John H. Walton. Survei Perjanjian Lama. Terj. Yayasan Penerbit Gandum Mas (1996). Malang: Yayasan Penerbit Gandum Mas, 1991.

Kung, Hans. Eternal Life. New York: Double Day \& Company Inc., 1984. Murphy, Roland E. "Ecclesiastes (Qoheleth)". Raymond E. Brown, et al. (eds.). The Jerome Biblical Commentary (Volume 1). New Jersey: PrenticeHall, Inc.: 534-540, 1968.

Murphy, Roland E. "Introduction to Wisdom Literature". Raymond E. Brown et al. (eds.). The Jerome Biblical Commentary (Volume 1). New Jersey: Prentice-Hall, Inc.: 487-494, 1968.

Ryder, E.T. "Ecclesiastes". Matthew Black \& H.H. Rowley (eds.). Peake's Commentary on the Bible. Berkshire [England]: Van Nostrand Reinhold (UK) Co. Ltd, 1962.

Schubert, K. "Talmud". Thomas Carson et al. (eds.). The New Catholic Encyclopedia, Second Edition [Volume 13]. Washington D.C.: The Catholic Universitty of America, 2003.

Scott, R.B.Y. Proverbs - Ecclesiastes: Introduction, Translation, and Notes. New York, Garden City: Doubleday \& Company, Inc., 1965.

Weiden, Wim van der. Seni Hidup: Sastra Kebijaksanaan Perjanjian Lama. Yogyakarta: Kanisius, 1995.

Weiden, Wim van der., dan I. Suharyo. Pengantar Kitab Suci Perjanjian Lama. Yogyakarta: Kanisius, 2000.

Lembaga Biblika Indonesia. Kitab Suci Perjanjian Lama (dengan Pengantar dan Catatan). Ende: Nusa Indah, 1988.

Suharyo, I. Mengenal Alam Hidup Perjanjian Lama. Yogyakarta: Kanisius, 1993.

- Membaca Kitab Suci: Mengenal Tulisan-Tulisan Perjanjian Lama. Yogyakarta: Kanisius, 1995. 


\section{Endnotes:}

1 Mahasiswa Program Studi Magister Ilmu Teologi, Universitas Katolik Parahyangan, Bandung. E-mail: andre_nur22@yahoo.com.

2 I. Suharyo, Membaca Kitab Suci: Mengenal Tulisan-Tulisan Perjanjian Lama (Yogyakarta: Kanisius, 1995) 12.

3 Kitab Suci Ibrani "Tanak" adalah singkatan yang mencerminkan tiga bagian Perjanjian Lama: (a) "T" (kitab-kitab Torah atau Taurat), "N" (Nevi'im atau kitabkitab nabi-nabi), Ketu'bim (tulisan-tulisan). Lih. Andrew E. Hill \& John H. Walton, Survei Perjanjian Lama (Terj. Yayasan Penerbit Gandum Mas [1996]. Malang: Yayasan Penerbit Gandum Mas, 1991) 32.

4 Suharyo, loc. cit.

5 Roland E. Murphy, "Introduction to Wisdom Literature" dalam Raymond E. Brown et al. (eds.), The Jerome Biblical Commentary - Volume 1 (New Jersey: Prentice-Hall, Inc.: 487-494, 1968) 488.

$6 \quad$ Ibid., 492.

7 E.T. Ryder, "Ecclesiastes" dalam Matthew Black \& H.H. Rowley (eds.), Peake's Commentary on the Bible (Berkshire [England]: Van Nostrand Reinhold (UK) Co. Ltd, 1962) 460.

8 J.D. Douglas, Ensiklopedi Alkitab Masa Kini (Jilid I: A-L), Terj. Yayasan Komunikasi Bina Kasih (Jakarta: Yayasan Komunikasi Bina Kasih, 1995) 391.

9 Wim van der Weiden, Seni Hidup: Sastra Kebijaksanaan Perjanjian Lama (Yogyakarta: Kanisius, 1995) 18.

10 Suharyo, op. cit., 83.

11 Murphy, art. cit., 489.

12 R.B.Y. Scott, Proverbs - Ecclesiastes: Introduction, Translation, and Notes (New York, Garden City: Doubleday \& Company, Inc., 1965) 192.

13 Ibid., 193.

14 Ibid., 195, 209.

15 Bdk. F. Buck, "Ecclesiastes" dalam Reginald C. Fuller et al. (eds.), A New Catholic Commentary on Holy Scripture (Hongkong: Thomas Nelson LTD: 512-521, 1975) 512; Anthony R. Ceresko, Introduction to The Old Testament: A Liberation Perspective (Quezon City: Claretian Publications, 1992) 287.

16 Koleksi Talmud tentang beragam ajaran dari para rabi Yahudi ini setidaknya telah beradar luas setelah abad ke-6 M; lih. K. Schubert, "Talmud" dalam Thomas Carson et al. (eds.), The New Catholic Encyclopedia, Second Edition [Volume 137 (Washington D.C.: The Catholic Universitty of America, 2003) 742.

17 L.F. Hartman, "Mishnah" dalam Thomas Carson et al. (eds.), The New Catholic Encyclopedia, Second Edition [Volume 9] (Washington D.C.: The Catholic Universitty of America, 2003) 672.

18 Ketika menjalani pembuangan di Babel, orang-orang Israel di pembuangan menggunakan bahasa Aram sebagai bahasa sehari-hari. Hal ini terus berlangsung setelah mereka kembali dari pembuangan di Babel, karena di masa Yesus pun, rakyat di Palestina berbahasa Aram; lih. C. Groenen, Pengantar ke Dalam Perjanjian Lama (Yogyakarta: Kanisius, 1980) 17. 
19 M.J. Dahod menemukan bahwa kitab Pengkhotbah memang ditulis dalam bahasa Ibrani, tetapi dalam "sistem ejaan" bahasa Fenisia, di bawah pengaruh kuat Sastra Canaannite-Phoenician (lih. Ryder, art. cit., 460).

20 Scott, op. cit., 198.

21 Ibid., 201.

22 Groenen, op. cit., 50.

23 Misalnya, dengan menerapkan aturan, bahwa penduduk jajahan yang ingin menjadi pegawai di pemerintahan Yunani, haruslah menguasai bahasa dan budaya Yunani dengan menjadi lulusan di sekolah-sekolah kebijaksanaan Yunani di berbagai daerah. Lih. Wim van der Weiden dan I. Suharyo, Pengantar Kitab Suci Perjanjian Lama (Yogyakarta: Kanisius, 2000) 93.

24 Wim van der Weiden, op. cit., 271, 272.

25 Scott, op. cit., 200.

26 Hill \& Walton, op. cit., 478.

27 Ada dugaan bahwa kitab Pengkhotbah mulanya ditulis oleh seseorang, tetapi selanjutnya diterima dan diedit oleh penulis lain. Pengkhotbah 12:9-4 diduga adalah 'tambahan' dari penulis lain atau editor ini (Scott, op. cit., 256).

28 Penggunaan kata ganti 'aku' dalam penulisan kitab tidak menunjuk pada identitas pengarang, tetapi untuk memberikan efek dramatis dalam penulisan; lih. Murphy, "Ecclesiastes (Qoheleth)" dalam Raymond E. Brown, et al. (eds.). The Jerome Biblical Commentary (Volume 1). New Jersey: Prentice-Hall, Inc.: 534-540, 1968) 534.

29 Ryder, art.cit., 458

30 Murphy, "Introduction to Wisdom Literature", art. cit., 488.

31 Bagi pengarang Pengkhotbah, perjanjian Allah atas Israel adalah data yang tidak dapat 'diverifikasi'; lih. Scott, op. cit., 191.

32 Ibid., 196.

33 Hill \& Walton, op. cit., 482.

34 Scott, loc. cit.

35 Lembaga Biblika Indonesia (LBI), Kitab Suci Perjanjian Lama (dengan Pengantar dan Catatan) (Ende: Nusa Indah, 1988) 1106.

36 Ditemukan kemiripan tema Kitab Pengkhotbah dengan Sastra Hikmat Mesopotamia. Misalnya, tema "The Man Who Was Tired of Life' (ANET 406b, 407a), "Dialog about Human Misery"; lih. Murphy, "Introduction to Wisdom Literature", art. cit., 490, 492.

37 Suharyo, Mengenal Alam Hidup Perjanjian Lama (Yogyakarta: Kanisius, 1993) 83.

38 Scott, op. cit., 198.

39 Hans Küng, Eternal Life (New York: Double Day \& Company Inc., 1984) 106.

40 Suharyo, op. cit., 75.

41 Küng, loc. cit.

42 Murphy, "Introduction to Wisdom Literature", art. cit., 493.

43 Bdk. Ryder, art. cit., 459.

44 Murphy, "Ecclesiastes (Qoheleth)", art. cit., 535.

45 Scott, op. cit., 202.

46 Ibid., 203. 
MELINTAS 33.2.2017

47 Ibid., 205.

48 Ibid., 204.

$49 \quad \mathrm{EV}=$ English Version. Penomoran ayat dalam Kitab Suci berbahasa Inggris.

50 Ryder, art. cit., 459.

51 Pengkhotbah menghubungkan peristiwa-peristiwa dalam sebuah urutan yang ditetapkan Allah (bdk. Pkh. 1: 4-11). Lih. Murphy, 'Ecclesiastes (Qoheleth)”, art. cit., 536.

52 Ryder, art. cit., 462.

53 Murphy, "Ecclesiastes (Qoheleth)", loc. cit.

54 Ibid.

55 Ryder, loc. cit.

56 Murphy, loc. cit.

57 Ryder, loc. cit. 